\title{
Personal Traits of the Entrepreneurs to Start the Enterprises at Industrial Estates in Southern Districts of Tamilnadu
}

\section{Selvaraj Narayanan*}

Department of Commerce, Saraswathi Narayanan College, Madurai, Tamilnadu, India

\begin{abstract}
The problem of entrepreneurial shortage as it affects the growth of industry in the less developed countries would seem to have two mutually reinforcing aspects i) The economic environment not generally conducive to the emergence and training of the persons likely to prove successful in initiating industrial activities, and (ii) That even if there was a good supply of such persons, their task as industrial entrepreneurs in a pre-industrial economy would tend to be an extremely difficult one. They shall have to start from the scratch. The personal traits of the respondents represent the psychological framework of the respondents to know the business opportunities and to start and manage the business. The personal traits consist of so many psychological aspects. Entrepreneurship is essential function and behaviour manifestation of a person for shifting resources from areas of low productivity to higher productivity. It is traits like willingness to take risk, high economic achievement motivation, self-confidence, problem solving disposition, adequate knowledge and skill, ability to face uncertainty and good managerial ability. This study will be of immense use for the policy makers and administrators engaged in the development of the small scale industrial sector in the southern districts of Tamilnadu. This study may also be of good use to the academic fraternity engaged in the state's industrial development studies.
\end{abstract}

Keywords: Personal traits; Entrepreneurship; Industrial; Achievement

\section{Introduction}

The United Nations Industries Development organization, has defined industrial estates as "a planned clustering of industrial enterprises offering developed sites, pre-build factory accommodation and a variety of services and facilities to the occupants [1].

One of the factors inhibiting industrialisation of under developed countries is social deterrent, while others being economic, administrative and international factors. Industrialisation is not merely a technological revolution, but a social transformation also. Industrialisation in the least developed countries in the early stages followed western industrialization pattern. High rate of population growth, mass illiteracy, and low per capital income, paucity of capital, prevalence of caste system, factionalism and lack of entrepreneurial ability are the major social deterrents that hamper the industrialization of a nation $[2,3]$. Generally, due to the rigidity of the social system like the caste syndrome in India, there is general lack of industrial leadership and existence of rigid stratification of occupations which represent a considerable barrier to industrial development.

The problem of entrepreneurial shortage as it affects the growth of industry in the less developed countries would seem to have two mutually reinforcing aspects, (i) The economic environment not generally conducive to the emergence and training of the persons likely to prove successful in initiating industrial activities, and (ii) That even if there was a good supply of such persons, their task as industrial entrepreneurs in a pre-industrial economy would tend to be an extremely difficult one. They shall have to start from the scratch. In order to obviate this difficulty, the governments of the many developing nations have taken upon themselves the task of starting new industries, providing technical education including training of managerial personnel etc. Besides, the governments also play a predominate role in promoting industrial activities particularly in the development of industrially backward areas through incentives like granting concessional finance, providing infrastructural facilities, supplying essential raw-materials, extension activities, fiscal incentives etc. All the state governments in India, usually through their state industrial Development Corporations have set up agencies for such infrastructural development. The Andhra Pradesh Infrastructure Corporation, the West Bengal infrastructure development corporation, Tamilnadu small Industries Development Corporation (TNSIDCO) and State Industries Promotion Corporation of Tamilnadu (SIPCOT) are some of the state agencies promoting industrial development.

This study will be of immense use for the policy makers and administrators engaged in the development of the small scale industrial sector in the southern districts of Tamilnadu. This study may also be of good use to the academic fraternity engaged in the state's industrial development studies. This study may also be useful for any interested entrepreneur who may like to make a foray into the realm of small sector industries. This study may also be of good use for any lay reader who may be interested to browse into the specifics of small scale industrial sector development in the southern districts of Tamil Nadu.

\section{Data source}

he study is based on both primary data. Primary data have been collected from the selected entrepreneurs in the southern districts (Madurai, Theni, Dindigul, Virudhunagar, Ramanathapuram and Sivaganga) of Tamil Nadu with the help of an interview schedule. Secondary data have been obtained from the books, journals, web sites and unpublished records.

\section{Period of the Study}

The primary data relating to the entrepreneurs of has been collected during 2014-2015.

*Corresponding author: Selvaraj Narayanan, Department of Commerce, Saraswathi Narayanan College, Madurai, Tamilnadu, India, Tel: 09843727975 E-mail: selvaraj narayanan@yahoo.com

Received November 10, 2015; Accepted December 15, 2015; Published December 21, 2015

Citation: Narayanan S (2015) Personal Traits of the Entrepreneurs to Start the Enterprises at Industrial Estates in Southern Districts of Tamilnadu. Int $\mathrm{J}$ Econ Manag Sci 5: 306. doi:10.4172/21626359.1000306

Copyright: (c) 2015 Narayanan S. This is an open-access article distributed under the terms of the Creative Commons Attribution License, which permits unrestricted use, distribution, and reproduction in any medium, provided the original author and source are credited. 
Citation: Narayanan S (2015) Personal Traits of the Entrepreneurs to Start the Enterprises at Industrial Estates in Southern Districts of Tamilnadu. Int J Econ Manag Sci 5: 306. doi:10.4172/21626359.1000306

Page 2 of 5

\section{Personal traits}

The personal traits of the respondents represent the psychological framework of the respondents to know the business opportunities and to start and manage the business. The personal traits consist of so many psychological aspects.

Personal traits of the entrepreneurs are analysed in order to identify whether they have the requisite disposition to undertake activities, which are independent and self-sustaining thereby contributing to their entrepreneurship. The personal factors considered are information seeking, mass media exposure, social participation, cosmopolitans, level of aspiration, and attitude towards self-employment, scientific orientation, decision making ability, economic motivation, managerial ability, problem recognition, risk orientation, urban pull and extension contact.

The selected factors are assessed by a four-level formula. Using the following formula used the marks obtained by the respondents to find out the personal index of the respondents.

$$
P I=\frac{\sum_{i=1}^{n} P S i}{\sum_{i=1}^{n} E P S i} \times 100
$$

Whereas

$\begin{array}{lll}\text { PI } & = & \text { Personal Index } \\ \text { PS } & = & \text { Personal Factors score } \\ \text { MSP } & = & \text { Maximum score of the personality } \\ \text { i.....n } & = & \text { Number of Personal Factors }\end{array}$

The average score of the different personal factors calculated among the entrepreneurs is presented in Table 1.

It is inferred from Table 1 that the entrepreneurs are very good in the aspects of decision-making ability, attitude towards self-employment, problem recognition and mass media exposure. The mean values of personal factors are 3.32, 3.24, 3.23 and 3.22, respectively. The average score of the personal traits of entrepreneurs is 2.6864 .

The respondents according to personal index are presented in Table 2.

Table 2 shows that $75(33.33 \%)$ respondents have the personal index of 41-60. Next to it $61(27.11 \%)$ respondents have the personal index of 61-80. Thirdly 51 (22.67\%) respondents are having a personal

\begin{tabular}{|l|l|}
\hline Personal Traits & Average Score \\
\hline Information Seeking & 2.85 \\
Mass media Exposure & $3.22(4)$ \\
Social participation & 2.61 \\
Cosmopoliteness & 1.85 \\
Level of aspiration & 2.63 \\
Attitude towards self-employment & $3.24(2)$ \\
Scientific Orientation & 1.45 \\
Decision making ability & $3.32(1)$ \\
Economic motivation & 2.85 \\
Managerial ability & 3.09 \\
Problem recognition & $3.23(3)$ \\
Risk taking willingness & 3.04 \\
Urban pull & 2.14 \\
Extension contact & 2.09 \\
\hline Overall & 2.6864 \\
\hline
\end{tabular}

Table 1: Personal traits of the respondents.

\begin{tabular}{|c|c|c|}
\hline Personal Index & Number of Respondents & Percentage \\
\hline Upto 20 & 12 & 5.33 \\
\hline $21-40$ & 51 & 22.67 \\
\hline $41-60$ & 75 & 33.33 \\
\hline $61-80$ & 61 & 27.11 \\
\hline Above 80 & 26 & 11.56 \\
\hline Total & 225 & 100 \\
\hline
\end{tabular}

Table 2: Personal traits index of the respondents.

\begin{tabular}{|c|c|c|}
\hline Category & Characteristic & Competencies \\
\hline \multirow{13}{*}{ Psychological } & Need for achievement & Initiative \\
\hline & Need for power & $\begin{array}{l}\text { Identifying and acting on } \\
\text { opportunities persistence, Seeking } \\
\text { information, concern for high quality } \\
\text { work commitment to work contact } \\
\text { Efficiency orientation }\end{array}$ \\
\hline & Independence & System scanning \\
\hline & Propensity to take risk & Problem solving \\
\hline & Drive & \\
\hline & Self-confidence and will power & \\
\hline & Creativity & \\
\hline & Ambition & \\
\hline & Discipline & \\
\hline & Recognition & \\
\hline & Benevolence & \\
\hline & Diligence & \\
\hline & Adaptability & \\
\hline \multirow[t]{4}{*}{ Economic } & Raising finance & Self-Confidence \\
\hline & Business experience & \\
\hline & Occupational background & \\
\hline & Leadership & Assertiveness \\
\hline \multirow[t]{2}{*}{ Sociological } & Social mobility & Persuasion \\
\hline & Family background & Use of influencing Strategies. \\
\hline \multirow[t]{3}{*}{ General } & Good Salesmen & \\
\hline & Pleasing personality & \\
\hline & Integrity & \\
\hline
\end{tabular}

Table 3: Characteristics and competencies of entrepreneurs.

index of 21-40. The respondents who have an index of above 80 constitute only $11 \%$.

\section{Entrepreneurship}

It appears that entrepreneurship is essential function and behaviour manifestation of a person for shifting resources from areas of low productivity to higher productivity. It is traits like willingness to take risk, high economic achievement motivation, self-confidence, problem solving disposition, adequate knowledge and skill, ability to face uncertainty and good managerial ability. The characteristics and competencies of the entrepreneurs are classified under psychological, economic, sociological and general categories by Mansfield. These are presented in Table 3.

The most frequent characteristics of the entrepreneurs identified by Madhu Murthy [4] are self-confidence, perseverance, determination, energy, diligence, resourcefulness, initiative, flexibility, positive response to challenges, independence, foresight, dynamism, leadership, versatility, knowledge of product, product and technology, responsiveness, profit orientation, perceptiveness and optimism.

The entrepreneurship in the present study is estimated with help 
Citation: Narayanan S (2015) Personal Traits of the Entrepreneurs to Start the Enterprises at Industrial Estates in Southern Districts of Tamilnadu. Int J Econ Manag Sci 5: 306. doi:10.4172/21626359.1000306

Page 3 of 5

of five important aspects namely self-confidence, task-orientation, risk bearing leadership and originality. Each aspect is estimated with the help an index. These aspects and the related variables are given in Table 4.

The components of the entrepreneurship are rated at four-point scale. The marks obtained by the respondents were used to find out the entrepreneurship index of the respondents.

The average score obtained by the entrepreneurs for each component of entrepreneurship variables is calculated and the resultant average score is shown in Table 5 .

It is noticed from Table 5 that entrepreneurship is found high with aspects namely individuality, risk taking, profit orientation, time management and creativity. The means score values of these entrepreneurship are $3.75,3.51,3.49,3.45$ and 3.40 respectively. The overall average of entrepreneurship variables among the entrepreneurs is 2.9135 .

The distribution of the respondents according to their entrepreneurship is exhibited in Table 6.

It is understood from Table 6 that majority 78 (34.67\%) respondents have entrepreneurial index of 41-60. Next, 65 (28.89\%) of them having an index of 61-80. The entrepreneurs who exceed an index of 80 are $18(8.00 \%)$, whereas $7.11 \%$ of the respondents are having of up to 20 .

\section{Association between socio-economic profile variables and entrepreneurship index}

The study of an association between the socio economic variables of entrepreneurs and entrepreneurship index are essential to need a special treatment to promote the entrepreneurship among the respondents. In order to analyse the association, twelve profile variables are taken into account [5]. The entrepreneurship index among the respondents is classified into five groups. The association between socio-economic profile variables with entrepreneurship index is analysed with the help of Chi-Square Test and the results are given in Table 7.

It is inferred from Table 7 that the association between

\begin{tabular}{|c|c|}
\hline Aspects & Components \\
\hline \multirow{4}{*}{ Self-confidence } & Confidence \\
\hline & Optimism \\
\hline & Independence \\
\hline & Individuality \\
\hline \multirow{4}{*}{ Task-Orientation } & Need for achievement \\
\hline & Profit Orientation \\
\hline & Future plan \\
\hline & Imitativeness \\
\hline \multirow{3}{*}{ Risk bearing } & Business Selection \\
\hline & Challenge Orientation \\
\hline & Risk Learning Level \\
\hline \multirow{5}{*}{ Leadership } & Decision-making \\
\hline & Headship \\
\hline & Leading \\
\hline & Sociability \\
\hline & Time Management \\
\hline \multirow{4}{*}{ Originality } & Resourcefulness \\
\hline & Versatility \\
\hline & Openness of mind \\
\hline & Creativity. \\
\hline
\end{tabular}

Table 4: Components of entrepreneurship index.

\begin{tabular}{|c|c|}
\hline Entrepreneurship Variables & Average score \\
\hline Confidence & 2.90 \\
\hline Optimism & 3.09 \\
\hline Independence & 3.15 \\
\hline Individuality & 3.75 \\
\hline Need for achievements & 2.99 \\
\hline Profit Orientation & 3.49 (3) \\
\hline Future plan & 3.24 \\
\hline Initiativeness & 2.69 \\
\hline Business Selection & 1.41 \\
\hline Challenge orientation & 2.81 \\
\hline Risk taking & $3.51 \quad(2)$ \\
\hline Decision making & 2.99 \\
\hline Headship & 1.51 \\
\hline Leading & 2.99 \\
\hline Sociability & 3.09 \\
\hline Time management & $3.45(4)$ \\
\hline Resourcefulness & 2.93 \\
\hline Versatility & 1.99 \\
\hline Openness & 2.89 \\
\hline Creativity & $3.40 \quad(5)$ \\
\hline Overall & 2.6135 \\
\hline Entrepreneurship Variables & Average score \\
\hline Confidence & 2.90 \\
\hline Optimism & 3.09 \\
\hline Independence & 3.15 \\
\hline Individuality & 3.75 (1) \\
\hline Need for achievements & 2.99 \\
\hline Profit Orientation & $3.49 \quad(3)$ \\
\hline Future plan & 3.24 \\
\hline Initiativeness & 2.69 \\
\hline Business Selection & 1.41 \\
\hline Challenge orientation & 2.81 \\
\hline Risk taking & 3.51 (2) \\
\hline Decision making & 2.99 \\
\hline Headship & 1.51 \\
\hline Leading & 2.99 \\
\hline Sociability & 3.09 \\
\hline Time management & 3.45 (4) \\
\hline Resourcefulness & 2.93 \\
\hline Versatility & 1.99 \\
\hline Openness & 2.89 \\
\hline Creativity & $3.40 \quad(5)$ \\
\hline Overall & 2.6135 \\
\hline
\end{tabular}

Table 5: Entrepreneurship among the respondents.

\begin{tabular}{|c|c|c|}
\hline Entrepreneurship Index & Number of Respondents & Percentage \\
\hline Upto 20 & 16 & 7.11 \\
\hline $21-40$ & 48 & 21.33 \\
\hline $41-60$ & 78 & 34.67 \\
\hline $61-80$ & 65 & 28.89 \\
\hline Above 80 & 18 & 8.00 \\
\hline Total & 225 & 100.00 \\
\hline
\end{tabular}

Table 6: Entrepreneurship index.

entrepreneurship and socio-economic variables namely age, education, family size, earning members, occupational background, monthly income and family income are significant at 5\% level since their Calculated Chi-Square value is greater than the table value. The other variables are not significantly associated with entrepreneurship.

\section{Correlation between personal traits and entrepreneurship}

The personal traits of the respondents are related with the psychological aspects of the respondents; how they view about enterprises, face risk and the like. The score of personal traits and entrepreneurship index of the respondents is separately calculated. The computed results of correlation coefficients of the personal traits and entrepreneurship are shown in Table 8. 


\begin{tabular}{|c|c|c|c|c|}
\hline Socio Economic profile & Calculated Chi-Square value & Degrees of freedom & Table value at $5 \%$ level & Significance \\
\hline Age & 39.411 & 12 & 21.026 & Significant \\
\hline Education & 41.421 & 8 & 15.507 & Significant \\
\hline Sex & 7.811 & 4 & 9.488 & Not significant \\
\hline Caste & 8.199 & 8 & 15.507 & Not significant \\
\hline Nature of Family & 7.916 & 4 & 9.491 & Not significant \\
\hline Nature of Status & 13.916 & 8 & 15.507 & Not significant \\
\hline Family Size & 19.211 & 8 & 15.507 & Significant \\
\hline Earning members per Family & 32.116 & 16 & 26.296 & Significant \\
\hline Occupational background & 36.216 & 20 & 31.410 & Significant \\
\hline Material Possession & 21.916 & 16 & 26.296 & Not significant \\
\hline Monthly income & 29.391 & 16 & 26.296 & Significant \\
\hline Family income per month & 29.15 & 8 & 15.507 & Significant \\
\hline
\end{tabular}

Table 7: Association between socio-economic profile and entrepreneurship.

\begin{tabular}{|l|l|}
\hline Personal Traits & Correlation Co-efficients \\
\hline Information Seeking & 0.1921 \\
Mass media exposure & -0.1971 \\
Social Participation & -0.1661 \\
Cosmopoliteness & -0.0896 \\
Level of aspiration & 0.2911 \\
Attitude towards self-employment & 0.1361 \\
Scientific Orientation & 0.2524 \\
Decision making ability & $0.5216^{*}$ \\
Economic Motivation & $0.5079^{*}$ \\
Managerial ability & $0.4164^{*}$ \\
Problem recognition & $0.4661^{*}$ \\
Risk taking willingness & $0.5362^{*}$ \\
Urban Pull & 0.1973 \\
Extension Contact & 0.1921 \\
\hline
\end{tabular}

Note: ${ }^{*}$ Indicates significant at $5 \%$ level.

Table 8: Correlation between personal traits and entrepreneurship.

It is inferred from Table 8 that there is a positive correlation between Entrepreneurship and the personal variables namely decision making ability, economic motivation, managerial ability, problem recognition and risk taking willingness since their correlation co - efficient are $0.5216,0.5079,0.4164,0.4661$, and 0.5362 respectively.

\section{Factors Influencing the Initiation to Start the Enterprise in the Industrial Estates}

The factors responsible for starting the enterprise by the respondents in the industrial estates are economic, social, psychological and environmental oriented. The present study confines the variables to economic independence, self-prestige, employment opportunities, technical knowledge, urge to achieve, aspiration about children, financial assistance, use of idle funds, self-interest, encouragement of family members, organizational skill, self-employment, revival of sick unit, social status, entrepreneurial experience, family background, traditional/hereditary, market potential, earning income, more dependents, unemployment and challenge seeking. The respondents at five-point scale rate the said 22 variables namely highly important, important, moderate, not important and not at all important with score values of 5, 4, 3, 2 and 1 respectively. The principal factor analysis method with Orthogonal Varimax Rotation is used to identify the factors that contributed to the initiation and management of the enterprise.

The twenty two variables included in the factor analysis reveals that four factors influence the initiation to start the enterprises in the industrial estates namely (i) Achievement and support factor, (ii) Interest factor, (iii) Traditional status factor and (iv) Economic necessity factor. The variables namely economic independence self-prestige, employment opportunities, technical knowledge, urge to achieve, aspiration about children, financial assistance and use of idle funds are included in achievement and support factor. The variables namely self-interest, encouragement of family members, organizational skill, self-employment and revival of sick unit are clustered into the interest factor. The traditional status factor includes the variables namely social status, entrepreneurial experience, family background and traditional/ hereditary whereas the economic necessity factor includes market potential, the earning income, more dependents, unemployment and challenge seeking.

The communality value (h2) as shown in Table 9 indicates the power of variable to explain the factor altogether. A higher communality represents the degree of variable that explains the factors together are higher. By communality values, the important variables that influence the respondents to the initiation and management of the enterprise are economic independence, self-interest and technical knowledge since the communality values are $0.8919,0.8180$ and 0.7460 respectively.

The Eigen value of the factor indicates the degree of factor which explains the variables altogether. A higher Eigen value shows greater intensity of the factor that explains the variables altogether. By Eigen values, the most important factors that influence the respondents to the initiation and management of the enterprises are achievement and support factor and interest factor since the Eigen values are 4.3854 and 2.8899 respectively.

\section{Conclusion and Summary}

Personal traits of the entrepreneurs are analysed in order to identify whether they have the requisite disposition to undertake activities, which are independent and self-sustaining thereby contributing to their entrepreneurship. The entrepreneurs are very good in the aspects of decision-making ability, attitude towards self-employment, problem recognition and mass media exposure. The mean values of personal factors are 3.32, 3.24, 3.23 and 3.22, respectively. The most frequent characteristics of the entrepreneurs identified self-confidence, perseverance, determination, energy, diligence, resourcefulness, initiative, flexibility, positive response to challenges, independence, foresight, dynamism, leadership, versatility, knowledge of product, product and technology, responsiveness, profit orientation, perceptiveness and optimism. The Eigen value of the factor indicates the degree of factor which explains the variables altogether. A higher Eigen value shows greater intensity of the factor that explains the variables altogether. By Eigen values, the most important factors that influence the respondents to the initiation and management of the enterprises are achievement and support factor and interest factor since the Eigen values are 4.3854 and 2.8899 respectively.

\section{Suggestions}

Integration of promotional programmes for the sector should 
Citation: Narayanan S (2015) Personal Traits of the Entrepreneurs to Start the Enterprises at Industrial Estates in Southern Districts of Tamilnadu. Int J Econ Manag Sci 5: 306. doi:10.4172/21626359.1000306

Page 5 of 5

\begin{tabular}{|c|c|c|c|c|c|}
\hline \multirow[t]{2}{*}{ Motivation Variables } & \multicolumn{4}{|c|}{ Rotated Factor Loading } & \multirow[t]{2}{*}{ h2 } \\
\hline & F1 & F2 & F3 & F4 & \\
\hline Economic Independence & 0.8124 & 0.3514 & 0.2616 & -0.1999 & 0.8919 \\
\hline Self-Prestige & 0.7996 & 0.2364 & -0.0696 & -0.1926 & 0.7372 \\
\hline Employment Opportunities & 0.7536 & 0.0651 & 0.1996 & 0.2646 & 0.6820 \\
\hline Technical Knowledge & 0.6949 & 0.2969 & 0.3616 & 0.2103 & 0.7460 \\
\hline Urge to achieve & 0.6341 & 0.3816 & 0.3141 & 0.1949 & 0.6843 \\
\hline Aspiration about children & 0.5916 & 0.2969 & -0.3216 & 0.2415 & 0.5999 \\
\hline Financial Assistance & 0.5716 & 0.0981 & -0.1406 & 0.2964 & 0.4440 \\
\hline Use of idle funds & 0.5616 & 0.1869 & 0.2164 & -0.3114 & 0.4941 \\
\hline Self-Interest & -0.2916 & 0.7516 & 0.1921 & 0.3621 & 0.8180 \\
\hline $\begin{array}{l}\text { Encouragement of family } \\
\text { members }\end{array}$ & -0.2361 & 0.6610 & 0.2621 & 0.1921 & 0.5991 \\
\hline Organization Skill & 0.0619 & 0.5516 & 0.2461 & 0.2110 & 0.4131 \\
\hline Self-employment & 0.0691 & 0.5371 & 0.1921 & 0.2961 & 0.4178 \\
\hline Revival of sick unit & -0.1213 & 0.5216 & -0.2162 & 0.2461 & 0.3941 \\
\hline Social Status & 0.3341 & 0.2461 & 0.6621 & 0.3516 & 0.7342 \\
\hline Entrepreneurial Experience & 0.0491 & 0.2461 & 0.6121 & -0.0961 & 0.4469 \\
\hline Family background & 0.1621 & 0.4924 & 0.5216 & -0.2121 & 0.5858 \\
\hline Traditional/ Hereditary & 0.0962 & 0.1039 & 0.5124 & 0.1629 & 0.6582 \\
\hline Market Potential & 0.1324 & -0.2816 & 0.1241 & 0.5921 & 0.4628 \\
\hline Earning Income & 0.2061 & -0.1941 & 0.4216 & 0.5518 & 0.5624 \\
\hline More dependents & 0.3161 & -0.0916 & -0.2411 & 0.5349 & 0.4526 \\
\hline Unemployment & -0.2961 & 0.4516 & 0.3161 & 0.5226 & 0.6646 \\
\hline Challenge Seeking & 0.3121 & 0.4941 & -0.2941 & 0.5141 & 0.6923 \\
\hline Eigen Value & 4.3854 & 2.8899 & 2.5447 & 2.8653 & \\
\hline
\end{tabular}

Table 9: Factors influencing the initiation to start the enterprise in the industrial estates. be made with other areas of development programmes which could also correct the regional imbalances. Organisations of production and distribution functions with deliberate bias towards village and small scale industries sector in such a way as to create opportunities for fuller and additional employment on dispersed and decentralised basis; creation of suitable organisational base as various levels to implement the development of programmes for the sector should be attempted to. Some other notable support measures for the small enterprises include; reservation of items for exclusive production and purchase; provision of financial and fiscal incentives; supply of raw materials and machinery through the wide network of promotional bodies, viz., Small Industries Service Institutes (SISIs), District Industries Centres (DICs), Central Industries of Tool Design (CITD) Institute for Design and of Electrical measuring instruments (IDEM) and National Institute for Entrepreneurship and Small Business Development (NIESBUD). The success of EDPs, which has been conceived as integral part of promotional measures, will mean faster growth of small enterprises run by young and highly motivated entrepreneurs.

The promotion of industrial estates has to be combined with entrepreneurial response and capability. Therefore, identifying appropriate and effective entrepreneurial talent occupies a significant place in any programme related to the development of small scale.

\section{References}

1. United Nations Organization (1996) Study of Products and Plans and Progress of Industrial Estates. USA.

2. Nandapurker GG (1982) Small Farmers A study on their entrepreneurial Behaviour. Metropolitan Book Company Pvt Ltd, New Delhi, India.

3. Mansfield S (1987) The identification and Assessment of competencies and other personal characteristics of entrepreneurs in Developing Countries. Mc Ber \& co, Boston, USA

4. Murthy KM (2003) Entrepreneurs; Evaluation of the concept and characteristics SEDME 29: 12-17.

5. Grewal PS (1987) Methods of Statistical Analysis. Sterling Publishers Pvt Ltd New Delhi, India. 